\title{
Measuring customer preferences in the winter sports market: The case of Greece
}

Received (in revised form): 1st November, 2005

\section{George Siomkos}

is a lecturer of marketing at the University of Macedonia, Thessalonica, Greece. His research interests focus on empirical research in tourism studies, specifically in tourism destination marketing and management. His research is published in many refereed journals, such as the Journal of Tourism Management and the Journal of Tourism Analysis. He has also participated in several international conferences.

\section{Chris Vasiliadis}

is Professor of Marketing and Chairman of the Department of Business Administration, Athens University of Economics and Business. His research and teaching interests include consumer behaviour, strategic marketing and planning, crisis management, financial services marketing and strategic electronic marketing. He holds a BSc in marketing, an MBA in finance, an MSc in statistics and operations research, and an MPhil and PhD in marketing and corporate finance. He has published over 50 articles in academic journals and is the author of four marketing textbooks.

\section{Petros Lathiras}

is an external lecturer of postgraduate courses at the University of Macedonia. He is also an external consultant in various business ventures in both the private and public sector. His research interests cover tourism economics, marketing, statistics, finance and applied econometrics. He holds a BSc in applied economics, an MSc in business and economic forecasting and a $\mathrm{PhD}$ in applied econometrics.

\begin{abstract}
In a growing competitive international environment, the prediction of consumer preferences for multi-attribute products and services is a critical aspect for any marketing administration. Delivering a better combination of intrinsic attributes in a product and related services will help a company or organisation to create sustainable competitive advantage. Determining customer perception of value in the form of utilities can provide the marketing administration of a company with a functional tool to evaluate the usefulness of a product or a service characteristic. This paper identifies perceived values through a field study in tourism enterprises located in Greece. Questionnaires were conducted in 11 ski resorts, which varied in size, location, age and ownership structure. Conjoint analysis was applied to estimate the highest total value across the main service and product attributes offered by the resorts. Using logit models, the analysis was extended to identify the importance of consumer characteristics to the levels of seven product attributes.
\end{abstract}

Chris Vasiliadis Egnatia 156 st., Thessalonica 54 006, Greece

Tel. +30 2310891581 Fax: +30 2310891544 ; e-mail: chris@uom.gr

\section{INTRODUCTION}

Knowing where consumer preferences and their values reside, companies can develop the necessary marketing strategies to increase customer satisfaction, loyalty and retention, thus strengthening their competitive position.
It is impossible today to remain cost competitive and offer every feature desired by customers. ${ }^{1}$ Therefore, marketing, engineering and operations need to work together to determine the profit-maximising bundle of product features. Marketers are more likely to use 
conjoint analysis (CJA) to help design new product feature sets. Green and Krieger suggest the use of the CJA technique, for the detection of competitive actions and reactions in the case of introducing new products or services and extensions, through the analysis of consumers' preferences and perceptions. ${ }^{2}$ Use of this technique finds wider applications after 1985, in research and enterprise practice. This is also due to the easier management of mathematical data with the use of computers and corresponding software supporting applications based on the CJA technique. ${ }^{3}$

CJA is a survey-based multivariate technique that measures consumer preferences about the attributes of a product or a service. The goal is to identify the most desirable combination of features to be offered or included in the product or the service. The CJA process is supported by the theoretical admission that consumers simplify the complexity of a purchasing decision, selecting for themselves a subset of merchandise characteristics for which they give individual subject values, depending on the characteristic structure of those values. Respondents are told about the various combinations of features under consideration and are asked to indicate their first, second and third preference, and so on. The analysis calculates a value (or utility) for each feature. Features with the highest values are judged to be the most important to respondents.

The completion of a research problem concerning marketing administration using CJA is supported by a variety of alternative CJA techniques. The researcher can choose between various techniques, such as the full-profile, partial-profile, stated preferences (choice-based CJA), self-explicated preferences and configurator's techniques. ${ }^{4}$
The aim of this paper is to report the findings of an empirical research study to analyse skiing resort visitors' purchasing decisions on the basis of the value they attach to certain product attributes. The survey was supported by the Greek National Tourism Organisation and constitutes a part of a larger project which aims to construct qualitative indexes for the winter skiing industry. The results of the survey have an informative role and can be used as an advisory tool to guide marketing strategies aiming to improve the quality of services offered in winter skiing resorts.

The research was based on the full profile technique, which constitutes segmentation research characterised in marketing terminology as benefit segmentation, as the analysis is based on consumer benefits/values (perceived benefits). CJA's full profile technique analysis is based on product description using feature levels of the characteristics being analysed. The consumer categorises the products based on personal preferences (ranking evaluation method) or alternatively rates the investigated product offers (rating evaluation method) according to a scale of measurement. ${ }^{5} \mathrm{~A}$ classic application in marketing research, according to the full profile technique, is the example of planning a carpet cleaner product by Green and Wind. ${ }^{6}$ The present study also belongs to this category of CJA techniques.

The use of the full profile technique in CJA is widespread, but one of its basic disadvantages is considered to be the difficulty of gathering data from consumers when the total number of product choices is particularly high. Today, the possibility of depicting cards with the use of digital technology, as well as the processing of digital information, has opened new prospects for the extension of research activities in 
relation to CJA's technical applications. A characteristic example of presenting and analysing product offers with alternative features is the research presented on the Sloan Management School website. ${ }^{7}$ This study is particularly interesting to the present paper because it is addressed to internet users as well as to potential visitors of ski resorts. In particular, six product features are being investigated using electronic cards. These features, which also indirectly determine the importance of the analysis regarding the description of ideal ski resorts, are as follows: (a) ski terrain condition, (b) snow condition, (c) activities, (d) price, (e) distance and (f) level of crowding. After a relative briefing on the characteristics and the investigation alternatives, the web page visitor uses the mouse to select from all the proposed cards, with alternative combinations of characteristics, the choice that best expresses their feelings. ${ }^{8}$

As a post hoc implementation to the present study, a logit analysis was applied to identify the significance of the personal characteristics of respondents to their mean utilities. Findings have shown that certain personal characteristics contribute to higher perceived values for specific product and service attributes offered by the ski resorts.

\section{PRODUCT AND DEMAND}

The overall ski resort product on offer can be presented more analytically by using Porter's ${ }^{9}$ relative terminology (value chain terminology). The overall tourist product on offer can thus be subdivided into two basic activity categories. The first category includes primary activities that are related to the creation of the resort tourist product, which supply value to customers, while the second category encompasses support activities, and conditions that contribute to the output of main activities. In particular, the overall ski resort product on offer can be composed of the main activities that is - the tourist offices that promote the resort accommodation, restaurant and entertainment facilities, local transport and transport means enterprises, medical care, banking services, retail shops, local tourist attractions, learning and renting equipment faculties and policing services, as well as support activities and situations. All of the above comprises the comparative advantage of the region, the infrastructure in the region, services of administration of the overall tourist product offered, services of planning and advising and, finally, marketing services of the resort. ${ }^{10}$ These characteristics influence the visitors' experience, and the visitors to ski resorts usually express them as being important for determining the quality of their experience. ${ }^{11}$ Visitors commit these experiences to memory and create a relative value (utility) for themselves. It should be noted that during the decision-making process for a visitor to go to a ski resort, there are usually three main restrictive factors which can influence their stay at any of the destinations: time, family obligations and available income. ${ }^{12-14}$

\section{CONJOINT ANALYSIS PLANNING}

\section{Categories of product attributes}

In the present research, the CJA procedure was based on the selection of the most indicative attributes (ski resort attributes) related to the existing ski resorts in Greece.

In order to interpret these attributes, there were in-depth interviews with experts (eg skiing instructors) who had visited the Greek ski resorts. In addition, important material was collected from secondary information material such as specialised sports and economics 
Table 1: Investigated product attributes of ski resorts

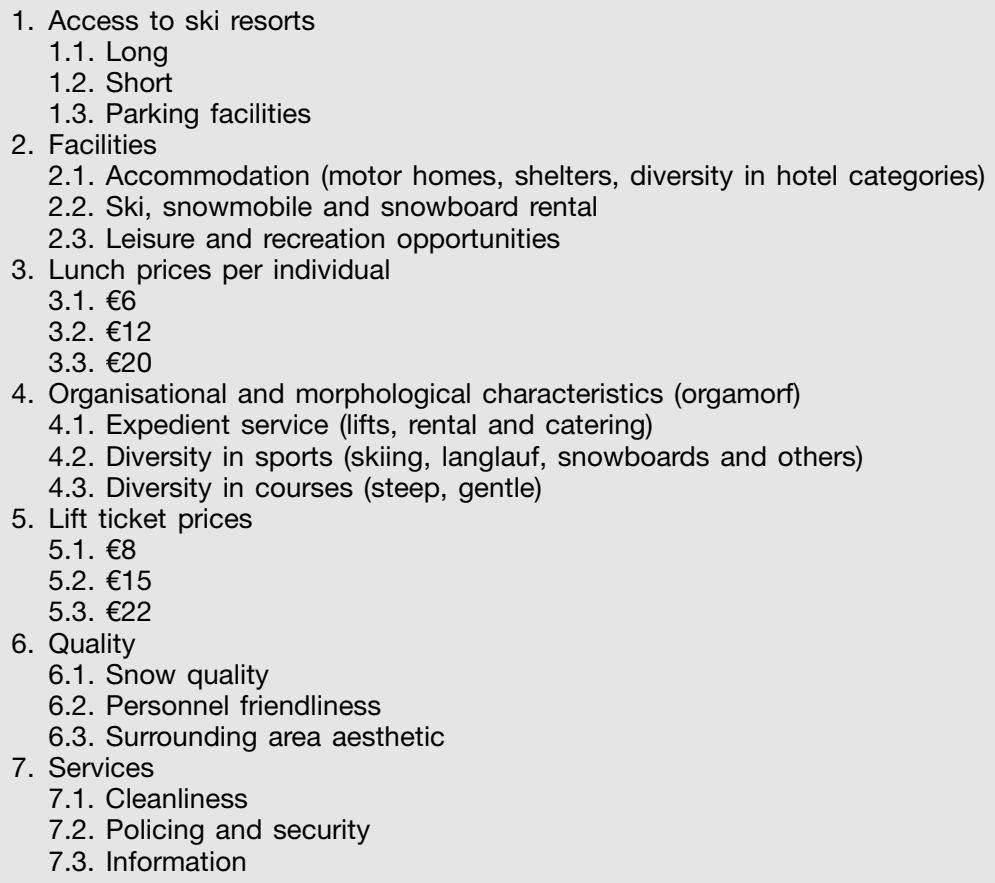

magazines and printed matter, as well as associated announcements published in known scientific journals. This secondary material was crossed with the results of qualitative research, namely the results of the in-depth interviews. Finally, seven categories of attributes have been chosen (Table 1). This number of categories was chosen because it is a manageable number, making it easy for respondents to estimate potential product combinations resulting from the crossing of attributes and their levels. ${ }^{15}$ There were also successful efforts with a number of other attributes in the research level. The design of the hotel chain Courtyard of Marriot is a typical case of CJA based on 50 attributes. ${ }^{16,17}$

\section{Levels of product attributes}

The levels of attributes were defined using the procedure that was followed during the examination of attributes of the winter sports destinations. In particular, following the in-depth interviews with experts, the levels estimating the attributes were selected in such a way that they covered the whole spectrum of the products and services actually rendered in ski resorts. The levels were chosen to include modern or high-quality services and products, as well as classic or low-quality services and products, a typical situation in numerous ski resorts in Greece and elsewhere. In addition, emphasis was placed on the same number of attributes because potential differences in the levels and/or close values between levels seem to affect the results describing the importance of each attribute. Consequently, there will be differences in the usefulness functions or functions of part-worths. ${ }^{18,19}$ The attributes of the afore-mentioned seven categories were selected in such a way as to satisfy all requirements for sufficiency, appeal and application.

Thus, in this case, visitors to ski resorts should estimate or classify 
Table 2: Ski resorts and the final distribution of total observations after the conjoint research

\begin{tabular}{llccc}
\hline Ski centre & Frequency & Percentage & $\begin{array}{c}\text { Valid } \\
\text { percentage }\end{array}$ & $\begin{array}{l}\text { Cumulative } \\
\text { percentage }\end{array}$ \\
\hline Falakro & 27 & 5.4 & 5.4 & 5.4 \\
Lailias & 51 & 10.2 & 10.2 & 15.6 \\
Seli & 40 & 8.0 & 8.0 & 23.6 \\
3-5 Pigadia & 55 & 11.0 & 11.0 & 34.7 \\
Elatochori & 20 & 4.0 & 4.0 & 38.7 \\
Vorras & 41 & 8.2 & 8.2 & 46.9 \\
Vigla & 65 & 13.0 & 13.0 & 59.9 \\
Vasilitsa & 37 & 11.8 & 7.4 & 67.3 \\
Pelion & 59 & 4.0 & 11.8 & 79.2 \\
Karpenisi & 20 & 6.2 & 4.0 & 83.2 \\
Parnassus & 31 & 10.6 & 6.2 & 89.4 \\
Other & 53 & 100.0 & 10.6 & 100.0 \\
Total & 499 & & 100.0 & \\
\hline
\end{tabular}

according to order of preference $(3 \times 3 \times 3 \times 3 \times 3 \times 3 \times 3)$

$\times 37=2,187$ product descriptions. CJA can be based on the main influences of product attributes that are defined through a simplified table of orthogonal analysis (orthoplan). As a result, the product descriptions are radically reduced (18 in the present case), and the independence between attributes is secured.

Data analysis was performed with SPSS 10.1 software. Following the completion of the orthogonal analysis table, 18 design cards resulted. Regarding the holdout cards, four cards deriving from an alternative orthogonal analysis table were used. Therefore, the candidates responding to questionnaires had 22 cards for evaluation.

\section{Methodology}

Active visitors to winter sports destinations in Greece were the subjects examined in the present experiential research; services/product attributes and the whole tourism product rendered in these destinations were the object of examination. It was assumed that visitors evaluated the rendered product

highlighting the product attributes of winter sports destinations with important values or use for them. These values or utilities constitute the basis for interpreting an ideal model ski resort, including the most important product attributes and services required by the average visitor. The mathematical expression, including preferences or value utilities expressed by visitors, can be interpreted as a function of use, taking values for each of the attributes examined.

The basis for designing the desired winter sports destinations according to demand, is the ability to monitor values expressed by visitors for the examined product attributes and services through the formation of utility functions. CJA is the most fitting technique, and this was selected in order to examine the proper, preferred attributes of demand. This technique enables the examination of partial values that, if added, give the entire value of a product proposed to consumers (in this case, the ideal model ski resort).

\section{Sample and data collecting process}

During the 2003-2004 winter season, groups of students used the random-sample technique and examined 499 comments from people frequently visiting ski resorts (Tables 2 and 3). 
Table 3: Other variables describing the sample

\begin{tabular}{|c|c|c|c|}
\hline Variables and variable value categories & Frequency & Percentage & $\begin{array}{l}\text { Cumulative } \\
\text { percentage }\end{array}$ \\
\hline \multicolumn{4}{|l|}{ Visitor gender } \\
\hline Female & 226 & 45.3 & 45.3 \\
\hline Male & 273 & 54.7 & 100.0 \\
\hline Total & 499 & 100.0 & \\
\hline \multicolumn{4}{|l|}{ Visitor age (years) } \\
\hline $7-17$ & 32 & 6.4 & 6.4 \\
\hline $18-25$ & 194 & 39.0 & 45.5 \\
\hline $26-37$ & 155 & 31.2 & 76.7 \\
\hline $38-47$ & 72 & 14.5 & 91.1 \\
\hline $48-56$ & 35 & 7.0 & 98.1 \\
\hline Over 57 & 9 & 1.9 & 100 \\
\hline Total & 497 & 100 & \\
\hline \multicolumn{4}{|l|}{ Visitor occupation } \\
\hline Private sector employee & 92 & 18.4 & 18.6 \\
\hline Unemployed & 14 & 2.8 & 21.4 \\
\hline Other & 20 & 4.0 & 25.1 \\
\hline Unskilled labour & 12 & 2.4 & 27.5 \\
\hline University/college student & 140 & 28.1 & 55.5 \\
\hline Agriculture & 10 & 2.0 & 57.5 \\
\hline Household & 29 & 5.8 & 63.3 \\
\hline Government employee & 65 & 13.0 & 76.4 \\
\hline Senior executive & 6 & 1.2 & 77.6 \\
\hline School student & 32 & 6.4 & 84.0 \\
\hline Freelance professional & 79 & 15.9 & 100.0 \\
\hline Total & 499 & 100.0 & \\
\hline \multicolumn{4}{|l|}{ Level of education } \\
\hline Elementary education & 25 & 5.0 & 6.0 \\
\hline Secondary education & 179 & 35.9 & 41.9 \\
\hline Tertiary education & 262 & 51.5 & 93.4 \\
\hline Post-graduate education & 33 & 7.6 & 100.0 \\
\hline Total & 499 & 100.0 & \\
\hline \multicolumn{4}{|l|}{ Visitor place of residence and occupation } \\
\hline Thessalonica & 213 & 42.7 & 44.1 \\
\hline Athens & 57 & 11.4 & 56.9 \\
\hline Other & 229 & 45.9 & 100.0 \\
\hline Total & 499 & 100.0 & \\
\hline \multicolumn{4}{|l|}{ Monthly personal income $(€)$} \\
\hline Without a personal income & 165 & 33.3 & 33.3 \\
\hline Up to 500 & 72 & 14.5 & 47.9 \\
\hline $501-900$ & 94 & 19.0 & 66.9 \\
\hline $901-1,200$ & 73 & 14.7 & 81.6 \\
\hline $1,201-1,501$ & 43 & 8.7 & 90.3 \\
\hline Over 1,501 & 48 & 9.7 & 100.0 \\
\hline Total & 495 & 100.0 & \\
\hline \multicolumn{4}{|l|}{ Overall level of satisfaction } \\
\hline Particularly unsatisfied & 11 & 2.2 & 2.2 \\
\hline Unsatisfied & 29 & 5.9 & 8.1 \\
\hline Both satisfied and unsatisfied & 200 & 40.5 & 48.6 \\
\hline Satisfied & 200 & 40.5 & 89.1 \\
\hline Particularly satisfied & 59 & 10.9 & 100.0 \\
\hline Total & 499 & 100.0 & \\
\hline \multicolumn{4}{|l|}{ Desire to repeat visit to the same ski centre } \\
\hline Never in the future & 37 & 7.4 & 7.4 \\
\hline Possibly & 306 & 61.3 & 68.7 \\
\hline Immediately & 156 & 31.3 & 100.0 \\
\hline Total & 499 & 100.0 & \\
\hline
\end{tabular}

Standardised questionnaires (cards) were given to visitors to ski resorts (11 categories for each of the main ski resorts in Greece and a general category comprising the other ski resorts).

On each card (ie each page of the 
questionnaire), in addition to the combinations of indicative product attributes resulting from the formation of the orthogonal design process table, the afore-mentioned attributes were also presented as sketches so that visitors would be able to understand the combination of the entire product offer. For each of the 22 sketches of unique product attributes, visitors evaluated the entire product offer using a ten-point scale (the full profile evaluation process with rating scales). The 'zero' (0) value represented a 'very unwelcome ski resort', and 'ten' (10) represented a 'very welcome ski resort'.

In the standardised questionnaires, there were also questions with demographic and behavioural data concerning the description of visitors. In particular, the additional variables included in the questionnaire were gender, age, profession, degree of education, place of work, monthly income, level of satisfaction, the desire to visit the resort in the future, and an open question for comments and remarks about an ideal ski resort.

\section{Calculation method}

Values were calculated using the statistical package SPSS 10.1 with the ordinary least squares (OLS) regression parametric mathematic algorithm. This algorithm calculates partial values by homogenising the rate fluctuations based on the normal distribution while results agree with the results of the non-parametric techniques. ${ }^{20}$ Partial values were then used to calculate the total mean perceptual value or use that each one of the 20 examined ski resorts presented to the average visitor. The mathematical model interpreting the total utility perception of each ski resort, as expressed by the visitor in relation to the presented card of product characteristics, is given by the following formula:

$$
p_{i}=\beta_{0}+\sum_{j=1}^{M} u_{j k(i)}
$$

Where:

$$
\begin{aligned}
p_{i}= & \text { the total perceived utility of the } \\
& \text { ski resort } i \\
u_{j k}= & \text { partial utilities of } k \text { expression of } \\
& \text { the } j \text { attribute } \\
k_{(i)}= & \text { the product expression of the } i \\
& \text { ski resort in relation to } j \\
& \text { attribute } \\
\beta_{0}= & \text { the constant interpreting the } p \\
& \text { subindex for a hypothetical ski } \\
& \text { resort, which if its partial utilities } \\
& \text { are added then the value is equal } \\
& \text { to to zero. }
\end{aligned}
$$

The OLS technique presents the possibility of determining alternative forms of utility (part-worth ideal point models) based on values given by visitors in rating scales or relative preference ratings. In addition, this technique is recommended when there are a large number of product characteristics under examination. In the statistical program that was selected, the procedure is based on the OLS regression. ${ }^{21}$

\section{RESULTS OF CONJOINT AND LOGIT ANALYSIS}

The results represent the mean grading from people visiting ski resorts at the destinations examined and support the procedure for planning or re-planning winter sports destinations, taking into account the uses expressed by the average visitors. In this case, the overall results concerning 499 visitors of winter sports destinations are presented in Figure 1.

Based on the results, it is concluded that the product planning of winter sports destinations should be based on 


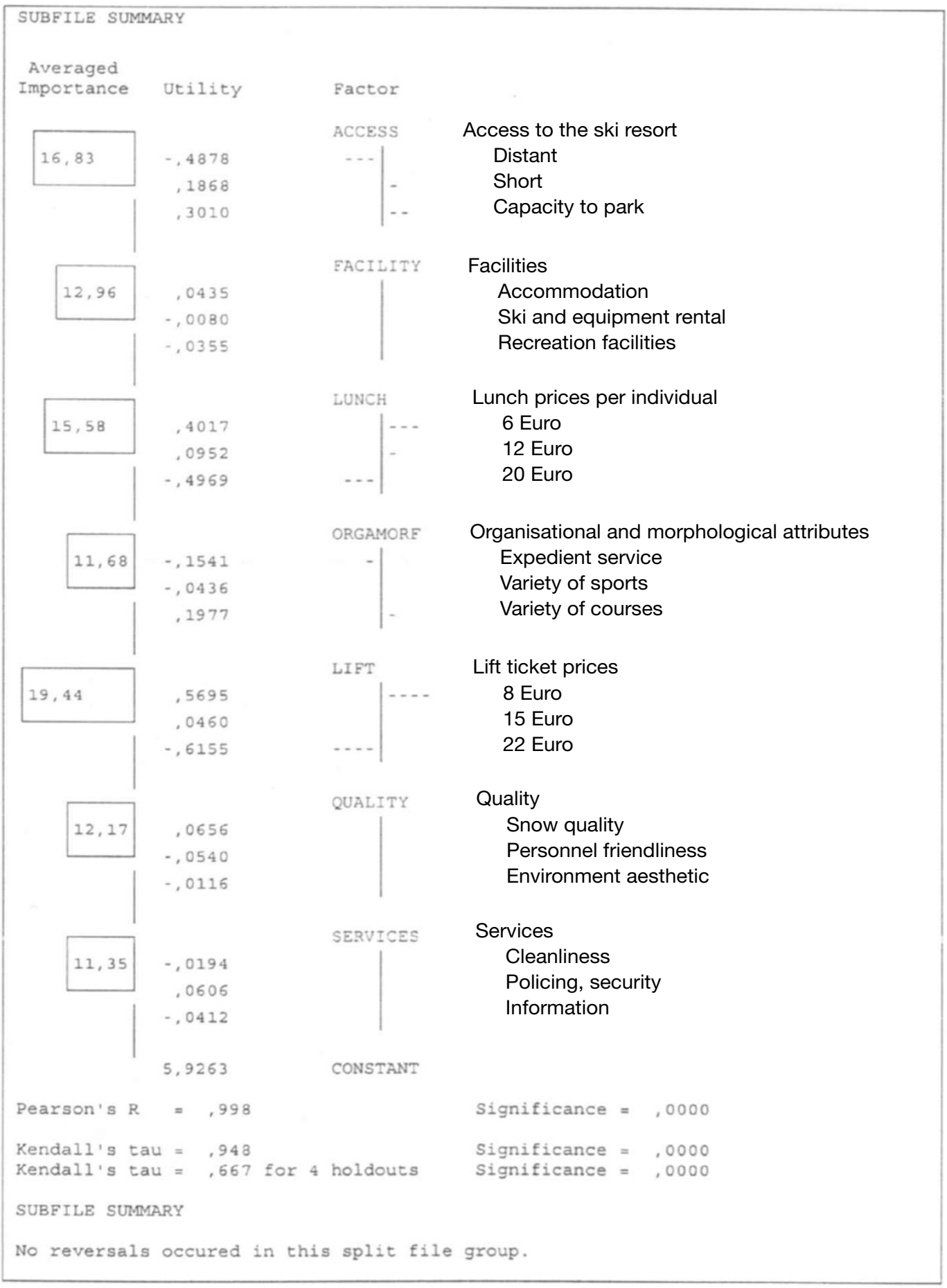

Figure 1 Presentation of total numerical mean values expressed by 499 visitors per investigated attribute

the costs of using lifts (see also Table 4, mean importance of lifts $=19.44$ per cent), the importance of access of (mean importance of access $=16.83$ per cent) and the prices of lunch (mean importance of lunch $=15.58$ per cent).

In detail, and bearing in mind the utility of investigated attributes which are 
Table 4: Logit model results for the total number of level attributes

\begin{tabular}{|c|c|c|c|c|c|c|}
\hline $\begin{array}{l}\text { Dependent } \\
\text { variable }\end{array}$ & Constant & Gender & Age & $\begin{array}{l}\text { Professional } \\
\text { occupation }\end{array}$ & Education & Income \\
\hline Access 1 & $\begin{array}{c}0.138 \\
(0.291)\end{array}$ & $\begin{array}{c}0.005 \\
(0.244)\end{array}$ & $\begin{array}{l}-0.003 \\
(-0.264)\end{array}$ & $\begin{array}{c}0.023 \\
(0.742)\end{array}$ & $\begin{array}{c}0.124 \\
(0.898)\end{array}$ & $\begin{array}{l}-0.064 \\
(-0.918)\end{array}$ \\
\hline Access 2 & $\begin{array}{l}-0.124 \\
(-0.264)\end{array}$ & $\begin{array}{l}0.0088 \\
(0.046)\end{array}$ & $\begin{array}{c}0.0138 \\
(1.363)\end{array}$ & $\begin{array}{c}0.0095 \\
(0.0308)\end{array}$ & $\begin{array}{l}-0.11426 \\
(-0.835)\end{array}$ & $\begin{array}{l}-0.0728 \\
-1.0453\end{array}$ \\
\hline Access 3 & $\begin{array}{l}-0.089 \\
(-0.189)\end{array}$ & $\begin{array}{l}-0.144 \\
(-0.751)\end{array}$ & $\begin{array}{l}0.005 \\
(0.052)\end{array}$ & $\begin{array}{l}-0.023 \\
(-0.763)\end{array}$ & $\begin{array}{l}0.059 \\
(0.430)\end{array}$ & $\begin{array}{l}-0.015 \\
(-0.216)\end{array}$ \\
\hline Facility 1 & $\begin{array}{c}0.181 \\
(0.383)\end{array}$ & $\begin{array}{c}0.144 \\
(0.751)\end{array}$ & $\begin{array}{l}-0.003 \\
(-0.256)\end{array}$ & $\begin{array}{l}-0.037 \\
(-1.203)\end{array}$ & $\begin{array}{l}-0.095 \\
(-0.070)\end{array}$ & $\begin{array}{c}0.041 \\
(0.597)\end{array}$ \\
\hline Facility 2 & $\begin{array}{l}-0.033 \\
(-0.071)\end{array}$ & $\begin{array}{c}0.107 \\
(0.562)\end{array}$ & $\begin{array}{l}-0.003 \\
(-0.071)\end{array}$ & $\begin{array}{l}-0.014 \\
(-0.446)\end{array}$ & $\begin{array}{c}0.062 \\
(0.453)\end{array}$ & $\begin{array}{l}-0.213 \\
(-0.309)\end{array}$ \\
\hline Facility 3 & $\begin{array}{l}-0.395 \\
(-0.839)\end{array}$ & $\begin{array}{l}-0.319 \\
(-1.663)^{\star}\end{array}$ & $\begin{array}{l}0.008 \\
(0.846)\end{array}$ & $\begin{array}{c}0.041 \\
(1.322)\end{array}$ & $\begin{array}{c}0.034 \\
(0.246)\end{array}$ & $\begin{array}{c}-0.022 \\
-(0.317)\end{array}$ \\
\hline Lift 1 & $\begin{array}{c}0.302 \\
(0.634)\end{array}$ & $\begin{array}{c}0.152 \\
(0.791)\end{array}$ & $\begin{array}{l}-0.009 \\
(-0.950)\end{array}$ & $\begin{array}{l}-0.053 \\
(-1.711)^{\star}\end{array}$ & $\begin{array}{l}-0.046 \\
(-0.337)\end{array}$ & $\begin{array}{c}0.027 \\
(0.390)\end{array}$ \\
\hline Lift 2 & $\begin{array}{l}-1.273 \\
(-2.629)\end{array}$ & $\begin{array}{c}0.165 \\
(0.861)\end{array}$ & $\begin{array}{l}0.024 \\
(2.311)^{\star \star}\end{array}$ & $\begin{array}{l}-0.008 \\
(-0.276)\end{array}$ & $\begin{array}{c}0.259 \\
(1.846)^{\star}\end{array}$ & $\begin{array}{l}-0.069 \\
(-0.992)\end{array}$ \\
\hline Lift 3 & $\begin{array}{c}0.503 \\
(1.066)\end{array}$ & $\begin{array}{c}0.038 \\
(0.201)\end{array}$ & $\begin{array}{c}0.002 \\
(0.164)\end{array}$ & $\begin{array}{c}0.008 \\
(0.275)\end{array}$ & $\begin{array}{l}-0.087 \\
(-0.639)\end{array}$ & $\begin{array}{l}-0.043 \\
(-0.621)\end{array}$ \\
\hline Lunch 1 & $\begin{array}{c}0.430 \\
(0.899)\end{array}$ & $\begin{array}{c}0.004 \\
(0.024)\end{array}$ & $\begin{array}{l}-0.009 \\
(-0.889)\end{array}$ & $\begin{array}{l}-0.057 \\
(-1.816)^{\star}\end{array}$ & $\begin{array}{l}-0.224 \\
(-1.613)^{\star}\end{array}$ & $\begin{array}{l}0.163 \\
(2.308)^{\star \star}\end{array}$ \\
\hline Lunch 2 & $\begin{array}{l}-0.571 \\
(-1.207)\end{array}$ & $\begin{array}{c}0.026 \\
(0.137)\end{array}$ & $\begin{array}{c}0.007 \\
(0.697)\end{array}$ & $\begin{array}{l}-0.049 \\
(-1.599)^{*}\end{array}$ & $\begin{array}{c}0.194 \\
(1.411)\end{array}$ & $\begin{array}{l}0.008 \\
(0.117)\end{array}$ \\
\hline Lunch 3 & $\begin{array}{l}-0.553 \\
(-1.156)\end{array}$ & $\begin{array}{c}0.068 \\
(0.353)\end{array}$ & $\begin{array}{c}0.011 \\
(1.089)\end{array}$ & $\begin{array}{l}0.068 \\
(2.176)^{\star \star}\end{array}$ & $\begin{array}{c}0.174 \\
(1.258)\end{array}$ & $\begin{array}{l}-0.149 \\
(-2.127)^{\star \star}\end{array}$ \\
\hline Orgamo 1 & $\begin{array}{c}0.391 \\
(0.828)\end{array}$ & $\begin{array}{c}0.200 \\
(1.044)\end{array}$ & $\begin{array}{c}0.002 \\
(0.195)\end{array}$ & $\begin{array}{l}-0.012 \\
(-0.390)\end{array}$ & $\begin{array}{l}-0.145 \\
(-1.052)\end{array}$ & $\begin{array}{l}0.035 \\
(0.513)\end{array}$ \\
\hline Orgamo 2 & $\begin{array}{l}-0.602 \\
(-1.274)\end{array}$ & $\begin{array}{l}-0.088 \\
(-0.462)\end{array}$ & $\begin{array}{c}0.016 \\
(1.560)^{\star}\end{array}$ & $\begin{array}{c}0.031 \\
(1.020)\end{array}$ & $\begin{array}{c}0.093 \\
(0.683)\end{array}$ & $\begin{array}{l}-0.086 \\
(-1.235)\end{array}$ \\
\hline Orgamo 3 & $\begin{array}{l}-0.127 \\
(-0.269)\end{array}$ & $\begin{array}{l}-0.053 \\
(-0.276)\end{array}$ & $\begin{array}{l}-0.011 \\
(-1.094)\end{array}$ & $\begin{array}{l}-0.012 \\
(-0.394)\end{array}$ & $\begin{array}{c}0.149 \\
(1.094)\end{array}$ & $\begin{array}{c}0.035 \\
(0.501)\end{array}$ \\
\hline Quality 1 & $\begin{array}{l}-0.418 \\
(-0.891)\end{array}$ & $\begin{array}{c}0.182 \\
(0.953)\end{array}$ & $\begin{array}{l}-0.002 \\
(-0.238)\end{array}$ & $\begin{array}{c}0.017 \\
(0.554)\end{array}$ & $\begin{array}{c}0.067 \\
(0.492)\end{array}$ & $\begin{array}{c}0.002 \\
(0.036)\end{array}$ \\
\hline Quality 2 & $\begin{array}{c}0.585 \\
(1.239)\end{array}$ & $\begin{array}{c}0.083 \\
(0.436)\end{array}$ & $\begin{array}{c}0.001 \\
(0.159)\end{array}$ & $\begin{array}{l}-0.073 \\
(-2.385)^{\star \star}\end{array}$ & $\begin{array}{l}-0.084 \\
(-0.611)\end{array}$ & $\begin{array}{c}0.010 \\
(0.149)\end{array}$ \\
\hline Quality 3 & $\begin{array}{c}0.136 \\
(0.290)\end{array}$ & $\begin{array}{c}0.067 \\
(0.353)\end{array}$ & $\begin{array}{c}0.002 \\
(0.164)\end{array}$ & $\begin{array}{c}0.008 \\
(0.275)\end{array}$ & $\begin{array}{l}-0.087 \\
(-0.639)\end{array}$ & $\begin{array}{l}-0.043 \\
(-0.620)\end{array}$ \\
\hline Service 1 & $\begin{array}{l}-0.141 \\
(-0.300)\end{array}$ & $\begin{array}{c}-0.342 \\
(-1.782)^{\star}\end{array}$ & $\begin{array}{c}0.011 \\
(1.146)\end{array}$ & $\begin{array}{c}0.038 \\
(1.230)\end{array}$ & $\begin{array}{l}-0.006 \\
(-0.044)\end{array}$ & $\begin{array}{l}-0.073 \\
(-1.045)\end{array}$ \\
\hline Service 2 & $\begin{array}{c}0.474 \\
(0.998)\end{array}$ & $\begin{array}{c}0.185 \\
(0.966)\end{array}$ & $\begin{array}{l}-0.025 \\
(-2.379)^{\star \star}\end{array}$ & $\begin{array}{l}-0.002 \\
(-0.068)\end{array}$ & $\begin{array}{l}-0.039 \\
(-0.284)\end{array}$ & $\begin{array}{c}0.066 \\
(0.946)\end{array}$ \\
\hline Service 3 & $\begin{array}{c}-0.119 \\
(-0.252)\end{array}$ & $\begin{array}{c}-0.157 \\
(-0.816)\end{array}$ & $\begin{array}{c}0.001 \\
(0.095)\end{array}$ & $\begin{array}{c}-0.109 \\
(-0.353)\end{array}$ & $\begin{array}{l}0.0798 \\
(0.583)\end{array}$ & $\begin{array}{c}0.0736 \\
(1.059)\end{array}$ \\
\hline
\end{tabular}

**Significance at 5 per cent level

*Significance at 10 per cent level

Figures in parentheses are $t$-ratios.

categorised according to seven attributes, a marketing mix strategy that would concern the product and price

arrangement would be to preserve the prices at low levels. More specifically, the average visitor's preference focuses on ticket price and lunch price as shown below:

- $€ 8$ for the lift ticket; and

- $€ 6$ or $€ 12$ for lunch.
In addition, the following attributes appear to be appealing to visitors:

- ski resorts that are close to visitors' point of departure (access); and - parking facilities (access).

During the planning and/or re-planning, special attention should also be given to the factors of facility, quality and services. In particular, the planning procedure 
should be based on the characteristics of each factor:

- overnight accommodation;

- snow quality;

- visitors' protection and safety.

As a post hoc implementation to the present analysis, a logit model was constructed to study the effect of the demographic and socioeconomic variables on the utilities assigned to the factors representing attributes. The rationale behind this analysis is that consumers are heterogeneous and therefore different consumers perceive different values within the same attribute or level of attribute, and this can affect the nature and the size of utilities. Furthermore, some of these variables can cause some utilities to be rated higher than others.

The dependent variable is expressed by the level of the product characteristic (eg Access 1, Access 2, Access 3 etc), taking the value of one if the value of the utility is above the mean, and zero if the value of the utility is below the mean. As there are three different levels for each of the seven product characteristics (eg access, lift, service etc), the total number of the estimated models was 21 . The explanatory variables used were: gender (GEN), age (AGE), professional occupation (PROF), level of education (EDU) and income (INC). The data used, excluding missed values, totalled 486. The 21 models were estimated using the method of maximum likelihood assisted by the MFIT V4 statistical package.

The results are presented in Table 4. Most variables do not show significant effects on the dependent variables. The gender dummy is insignificant except in the models representing the leisure and recreation potentiality (Facility 3 ) and the standard of cleanliness in the area (Service 1). Thus, for these two product characteristics, the gender factor makes it more likely to have utilities above the mean. Age appears to be important in contributing to high values of utility when it comes to security offered (Service 2) and to lift pricing policy, specifically that of $€ 15$. Age is also significant at the borderline level of 10 per cent in the model that corresponds to sport variety (Orgamo 2) available in the resort. Professional occupation is the most important explanatory variable, as it is significant in five equations. Three of these equations relate to the price of lunch, indicating the strong effects of occupation adding to the probabilities of significant changes in utility values. The variables of education and income level are also strongly related to the price of lunch. Education is less strong for lunch when its price is $€ 15$ or $€ 22$, while income is not significant for lunch with a price of $€ 15$. These results provide support that occupation, education and income level are important variables in affecting utility values corresponding to the price of lunch factor. These results probably reflect the Greek tendency to lay emphasis on food in their way of living.

According to CJA results, the attributes of quality and service should not be included in the best combination of features. In logit analysis, their corresponding utilities seem to be affected by the variables of profession and age. In particular, the utility related to safety and security (Service 2) in the resort area is significantly affected by the variable of age. In the same feature but at the level regarding cleanliness (Service 1 ), the gender variable seems to play an important role. The negative signs in Table 4 indicate that the more women (valued 0) there are in the resort, the greater the emphasis on cleanliness (utility above mean). As to the quality feature, profession is an important 
variable in shaping utility regarding the preference of personnel friendliness.

\section{CONCLUSIONS}

The main purpose of this paper was to provide the ski resort industry with information about the specific attributes of their products and services as perceived by their visitors.

The analysis focused on the relative desirability of the seven main system attributes of access, price of lunch, price of lift, quality, services, facilities and organisational and morphological characteristics of the resort.

CJA was applied to 499 questionnaires collected from 11 skiing resorts around Greece. The results have shown that visitors most value easy access to the resort, and the price of lifts and lunch, and place less value on the organisational and morphological aspects. Logit analysis revealed, however, that certain socioeconomic variables concerning visitors' characteristics play a significant role in shaping the importance of the underlying utilities, indicating that utilities are very likely to be sensitive to the structure of these variables.

The findings have important managerial and marketing implications. From the managerial perspective, this will allow managers of ski resorts to assess how they add value to the relationship with their visitors by focusing on the specific combination of features. Managers can also visualise any gaps between their own perceived value of what their resort offers and their visitors' perceived value, and then develop corrective action plans to reduce these gaps. Any such action can be expected to improve the individual resort's current position vis-à-vis competition. From a visitor's perspective, this will increase satisfaction, as they will feel that the product or service offered by the resort is equal or superior to what was expected. Knowing the customers' perceived value, the marketing administration of ski resorts will also help to create or correct marketing tools to increase demand and to devote more marketing resources to those features deemed important.

There are, however, certain restrictions in the present study, as well as some indications for further research. As far as the description of the sample is concerned, little attention is given to the segmentation procedures that could possibly end in modified or niche marketing strategies. Specific product combinations have not been analysed in this research. A researcher could examine the usefulness of promoting specific product characteristics in everyday practice, such as promoting an ideal ski product combination. This is possible with the use of specific statistical packages (eg SPSS 6.1 simulation card creation in orthoplan design). Due to the limitations in developing the statistical technique of CJA, one cannot possibly examine more than 20 suggested product combinations, and it is difficult to develop combinations with more than three levels of product characteristics as well as use of a variety of examined factor variables. This weakness is based on the difficulty that individuals had in replying to the standardised questionnaires, thus resulting in choosing variable categories and categories very carefully and after in-depth interviews. In the present research, the limitation was seven factor categories with three analysis levels. Thus, the conclusions of CJA focus on the levels of product characteristics and on the factor variables that were used in this research.

\section{References}

1 Pullman, M., Moore, W. and Wardell, D. G. (2002) 'A comparison of quality function deployment and conjoint analysis in new product design', Journal of 
Product Innovation Management, Vol. 19, No. 5, pp. 354-364.

2 Green, P. E. and Krieger, A. M. (1997) 'Using conjoint analysis to view competitive interaction through the customer's eyes' in Day G. S., Reibstein D. J, Gunther R. E. (eds) 'Wharton Dynamic Competitive Strategy', John Wiley \& Sons, New York, NY, pp. 343-366.

3 Wittink, D. R. and Cattin, P. (1989) 'Commercial use of conjoint analysis: an update', Journal of Marketing, Vol. 53, No. 3, July, pp. 91-96.

4 Hauser, J. R. and Rao, V. R. (2002). 'Conjoint analysis, related modelling, and applications', chapter prepared for 'Advances in Marketing Research Progress and Prospects, A tribute to Paul Green's Contributions to Marketing'; 23rd September. Available in 'publications', at: http://mitsloan. mit.edu/.

5 Orme, B. K. and King, W. C. (1998) 'Conducting full-profile conjoint analysis over the internet'. Sawtooth Software Research Paper Series, Sequim, Washington.

6 Green, P. E. and Wind, J. (1975) 'New way to measure consumers' judgments', Harvard Business Review; July-August, pp. 107-117.

7 Sloan Management School's website. Available at: http://conjoint.mit.edu/demos/ski/pages/intro1.html, last accessed 11th December, 2005.

8 Dahan, E. and Hauser, J. R. (2002) 'The virtual customer', The Journal of Product Innovation Management, Vol. 19, pp. 332-353.

9 Porter, M. E. (1985) 'Competitive Advance', The Free Press, New York, NY.

10 Flagestad, A. and Hope, C. A. (2001) 'Strategic success in winter sports destinations: A sustainable value creation perspective', Tourism Management, Vol. 22: pp. 445-461.

11 Ormiston, D., Gilbert, A. and Manning, R. E.
(1998) 'Indicators and standards of quality for ski resort management', Journal of Travel Research, Vol. 36, Winter, pp. 35-41.

12 Williams, P. W. and Lattey, C. (1995) 'Skiing constraints for women', Journal of Travel Research, Vol. 33, No. 2, pp. 21-25.

13 Kay, T. and Jackson, G. (1991) 'Leisure despite constraint: The impact of leisure constraints on leisure participation', Journal of Leisure Research, Vol. 23, No. 4, pp. 301-313.

14 Wright, B. A. and Goodale, T. L. (1991) 'Beyond non-participation: Validation of interest and frequency of participation categories in constraints research', Journal of Leisure Research, Vol. 23, No. 4, pp. 314-333.

15 Smith, S. L. J. (1993) 'Tourism Analysis: A Handbook' (3rd edn). Longman Scientific \& Technical, Singapore.

16 Wind, Y., Green, P. E., Shifflet, D. and Scarbrough, M. (1989) 'Courtyard by Marriott: Designing a hotel facility with consumer-based marketing models', Interfaces, Vol. 19, No. 1, pp. 25-47.

17 Teare, R., Mazanec, J. A., Welch, S. C. and Calver, S. (1994) 'Marketing in Hospitality and Tourism A Consumer Focus'. Cassell, London, UK, pp. 184-196.

18 Lilien, G. L and Rangaswamy, A. (2003) 'Marketing Engineering' (2nd edn)', Prentice Hall, NJ, p. 243.

19 Malhotra, N. K. and Birks, D. F. (2003) 'Marketing Research - An Applied Orientation' (3rd edn), FT Pearson Education, London, UK, pp. 629-30.

20 Green, P. E. and Krieger, A. M. (1993) 'Conjoint analysis with product-positioning applications', in Eliashberg, J. and Lilien, G. L. (eds) 'Marketing', North-Holland, Amsterdam, pp. 467-515.

21 Fox, J. (1997) 'Applied Regression Analysis, Linear Models, and Related Methods'. Sage, New York, NY. 